\title{
Pengaruh Risk Taking Terhadap Pembagian Dividen Pada Bank Umum Yang Terdaftar Di Bursa Efek Indonesia (BEI)
}

\author{
Jusmani ${ }^{1}$, Hendry Saladin ${ }^{2}$, Benny Usman ${ }^{3}$, Shelli Adelia ${ }^{4}$ \\ ${ }^{1}$ Fakultas Ekonomi dan Bisnis Universitas PGRI Palembang, jusmani@univpgri-palembang.ac.id \\ ${ }^{2}$ Fakultas Ekonomi dan Bisnis Universitas PGRI Palembang, hendrysaladin62@gmail.com \\ ${ }^{3}$ Fakultas Ekonomi dan Bisnis Universitas PGRI Palembang,benny usman@univpgri-palembang.ac.id \\ ${ }^{4}$ Fakultas Ekonomi dan Bisnis Universitas PGRI Palembang, Shellyadelia17@gmail.com
}

\begin{abstract}
ABSTRAK
Penelitian ini bertujuan untuk mengetahui apakah Risk Taking memiliki pengaruh terhadap pembagian Dividen. Variabel dalam penelitian ini terdiri dari variabel bebas yaitu risk taking yang diukur dengan menggunakan Z-score terhadap pembagian dividen yang diukur dengan dividend payout ratio (DPR). Data yang digunakan dalam penelitian ini adalah data laporan keuangan. Populasi dalam penelitian ini adalah seluruh bank umum yang terdaftar di Bursa Efek Indonesia (BEI) selama periode 2014-2018 yaitu sebanyak 43 bank. Berdasarkan kriteria dan karakteristik tertentu yang ditetapkan terdapat 10 sampel bank umum yang digunakan dalam penelitian ini, teknik pengambilan sampel menggunakan metode purposive sampling. Metode pengumpulan data menggunakan dokumentasi, sedangkan teknik analisis data menggunakan uji t atau regresi dan analisis deskriptif menggunakan program SPSS. Hasil penelitian ini membuktikan bahwa ada pengaruh risk taking terhadap pembagian dividen pada Bank Umum yang Terdaftar di Bursa Efek Indonesia periode 2014-2018. Tetapi, pengaruh yang dihasilkan tidak signifikan. Hal ini di karenakan hasil dari penelitian diketahui nilai $R$ sebesar 0,239 dan nilai $\mathrm{R}^{2}$ sebesar 0,057 dengan standar error sebesar 0,037. Dengan demikian, pengaruh risk taking terhadap pembagian dividen sebesar 5,7\%, sedangkan sisanya sebesar $94,3 \%$ dipengaruhi oleh variabel atau faktor lain yang tidak diteliti dalam penelitian. Risk-taking bukan merupakan satusatunya faktor yang mempengaruhi kebijakan dividen suatu bank. Terdapat beberapa faktor yang dapat menjelaskan mengapa argumen dalam hipotesis tidak diterima. Faktor yang pertama adalah ketaatan bank pada undang-undang (peraturan). Bank memilih untuk taat dari pada memanfaatkan celah undang-undang (peraturan) yang berlaku untuk mengambil keuntungan privat. Dalam risk-taking yang tinggi, bank lebih memilih menahan labanya dan tidak membagikan dividen. Kemungkinan yang terjadi yaitu bank memanfaatkan laba tersebut untuk menjaga kecukupan modal (capital adequacy) sesuai dengan ketentuan Bank Indonesia.
\end{abstract}

Kata Kunci: Risk Taking, Z-score, Pembagian Dividen

\section{ABSTRACT}

This study aims to determine whether risk taking has an effect on dividend distribution. The variable in this study consists of the independent variable, namely risk taking which is measured using the Zscore against the distribution of dividends as measured by the dividend payout ratio (DPR). The data used in this research is financial statement data. The population in this study were all commercial banks listed on the Indonesia Stock Exchange (BEI) during the 2014-2018 period, as many as 43 banks. Based on certain criteria and characteristics, there were 10 samples of commercial banks used in this study. The sampling technique used was purposive sampling method. Methods of data collection using documentation, while data analysis techniques using $t$ test or regression and descriptive analysis using the SPSS program. The results of this study prove that there is an effect of risk taking on dividend distribution in commercial banks listed on the Indonesia Stock Exchange for the period 2014-2018. However, the resulting effect is not significant. This is because the results of the study show that the $R$ value is 0.239 and the $R 2$ value is 0.057 with a standard error of 0.037 . Thus, the effect of risk taking on dividend distribution was $5.7 \%$, while the remaining $94.3 \%$ was influenced by variables or other factors not examined in the study. Risk-taking is not the only factor that affects a bank's dividend policy. There are several factors that can explain why the arguments in the hypothesis are not accepted. The first factor is the bank's compliance with laws (regulations). The bank chooses to obey rather than exploit the loophole of the law (regulation) to take private advantage. In high risktaking, banks prefer to hold their profits and not distribute dividends. What might happen is that the bank will take advantage of this profit to maintain capital adequacy in accordance with Bank Indonesia regulations.

Keywords: Risk Taking, Z-score, Dividend Distribution 


\section{A. PENDAHULUAN}

Laporan keuangan adalah laporan yang menunjukkan kondisi keuangan perusahaan pada saat ini atau dalam suatu periode tertentu yang menyajikan posisi keuangan dalam sebuah entitas. Tujuan umum dari laporan keuangan adalah untuk memberikan informasi yang terpercaya mengenai posisi keuangan,kinerja keuangan, dan arus kas dari entitas yang sangat berguna untuk membuat kepututusan ekonomi bagi para penggunanya.

Untuk mengetahui informasi yang tepat dalam laporan keuangan yaitu harus melihat informasi keuangan yang berkualitas, salah satu kriteria informasi yang berkualitas adalah relevan, yang berarti bahwa informasi dalam laporan keuangan dapat mempengaruhi keputusan ekonomi pemakai dengan membantu mereka mengevaluasi peristiwa masa lalu, masa kini atau masa depan,dan menegaskan atau mengoreksi, hasil evaluasi mereka di masa lalu.

Salah satu pengguna laporan keuangan dari pihak eksternal adalah investor, yang melakukan suatu investasi atau penanaman modal sesuai jenis investasi yang dipilih. Informasi dalam laporan keuangan dapat dijadikan bahan pertimbangan bagi investor untuk melakukan pengambilan keputusan investasi, salah satunya adalah investasi saham. Keuntungan yang didapatkan investor dalam investasi saham dapat berupa capital gain dan dividen. Capital gain adalah keuntungan yang diperoleh dari hasil penjualan saham, dimana hasil penjualannya lebih besar dibanding saat pembelian saham, sedangkan dividen merupakan bagian keuntungan perusahaan yang dibagikan kepada investor, pembagian dividen yang dilakukan oleh perusahaan kepada investornya dapat diukur dengan Dept Payout Ratio (DPR).

Salah satu hal yang dapat mempengaruhi kebijakan dividen adalah Risk Taking. Risk-Taking didefinisikan sebagai pengambilan aktivitas yang mengandung ketidakpastian atau resiko untuk meningkatkan keuntungan, dimana aktivitas tersebut mengandung kemungkinan kerugian dalam bentuk harta kehilangan keuntungan atau kemampuan ekonomis. Risk-Taking dapat diukur dengan menggunakan z-score untuk masing-masing bank. Hubungan Riskt-taking dengan pembayaran dividen diperusahaan non keuangan dan perusahaan keuangan tidak jauh berbeda, namun sejauh ini perilaku risk-taking pada industri perbankan masih mampu dikendalikan, hal ini dikarenakan bank merupakan regulated industries.

Penelitian ini mengambil sektor perbankan, dikarenakan perbankan merupakan salah satu komponen yang sangat penting dalam perekonomian nasional yaitu untuk menjaga kemajuan dan keseimbangan ekonomi nasional. Stabilitas industri perbankan sangat mempengaruhi stabilitas perekonomian nasional, dengan melakukan penalitian ini akan membuktikan adakah pengaruh pengambilan risiko bank terhadap pembagian dividen, karena pengambilan risiko terhadap pembagian dividen akan mempengaruhi kesetabilan perekonomian nasional.

\section{B. KAJIAN TEORI}

\section{Pengertian Bank dan Peranannya}

Presiden Republik Indonesia Mengesahkan Undang-Undang RI Nomor 10 Tahun 1998 tanggal 10 November 1998 tentang perbankan, yang dimaksud dengan bank adalah "Badan usaha yang menghimpun dana dari masyarakat dalam bentuk simpanan dan menyalurkannya kepada masyarakat dalam bentuk kredit dan atau bentuk-bentuk lainnya dalam rangka meningkatkan taraf hidup rakyat banyak".

Dari pengertian diatas dapat disimpulkan bahwa usaha bank selalu berkaitan dengan masalah keuangan seperti, menghimpun dana,menyalurkan dana, dan 
memberikan jasa lainnya. Dengan demikian bank sebagai suatu badan berfungsi sebagai perantara keuangan dari dua pihak, yaitu pihak yang kelebihan dana (surplus unit) dan pihak yang kekurangan dana (defisit unit). Hal inilah yang menyebabkan lembaga bank disebut sebagai lembaga kepercayaan, yang artinya pihak yang berkelebihan dana mempercayakan sepenuhnya kepada bank untuk dikelola dananya termasuk menyalurkannya kepada pihak yang kekurangan atau memerlukan dana dalam bentuk kredit.

Bank mempunyai empat alternatif sumber penghimpunan dana untuk kepentingan usahanya yaitu, dana sendiri, dana dari deposan, dana pinjaman, dan sumber dana lain yang berupa setoran jaminan, surat transfer, surat berharga pasar uang dan diskonto bank Indonesia.

\section{Risk Taking}

Kinanti (2015:5) mendefinisikan bahwa Risk-taking merupakan aktivitas mengambil risiko untuk memulai sebuah perusahaan atau meningkatkan keuntungan. Dimana risiko didefinisikan sebagai suatu kegiatan kemungkinan hasil yang diperoleh menyimpang dari yang diharapkan. Risiko muncul karena adanya ketidak-pastian yang mengandung kemungkinan kerugian dalam bentuk harta atau kehilangan keuntungan atau kemampuan ekonomis akan melemahkan permodalan bank, kesulitan permodalan dalam jumlah yang besar dan dalam waktu yang lama dapat meningkatkan potensi default risk bank (Indrayani, 2017:14)

Peraturan Bank Indonesia Nomor: 5/8/PBI/2003 mendefinisikan bahwa risiko sebagai potensi terjadinya suatu peristiwa yang dapat menimbulkan kerugian bank. Terdapat delapan jenis risiko yang ditanggung oleh bank, yaitu risiko kredit, risiko pasar, risiko likuiditas, risiko operasional, risiko hukum, risiko strategi, risiko kepatuhan, dan risiko reputasi.

\section{Z-Score}

Supardi (2016:73) menjelaskan bahwa metode Z-score (Altman) adalah skor yang ditentukan dari hitungan standar kali nisbah-nisbah keuangan yang akan menunjukkan tingkat kemungkinan kebangkrutan perusahaan. Berdasarkan pengertian diatas dapat disimpulkan bahwa metode z-score (Altaman) adalah suatu alat yang memperhitungkan dan menggabungkan beberapa rasio-rasio keuangan tertentu dalam perusahaan dalam suatu persamaan diskriminan yang akan menghasilkan skor tertentu yang akan menunjukkan tingkat kemungkinan kebangkrutan perusahaan.

Risk-taking dapat diukur dengan menggunakan Z-score untuk masing-masing bank. Berikut adalah rumus untuk menghitung risk-taking (LnZ).

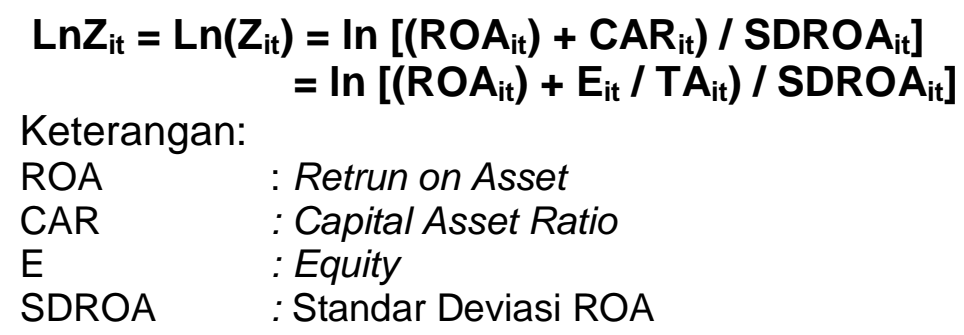

\section{Dividen dan Kebijakan Dividen}

Menurut Rudianto (2012:290) dividen adalah bagian laba usaha yang diperoleh perusahaan dan diberikan oleh perusahaan kepada pemegang sahamnya sebagai 
imbalan atas kesediaan mereka menanamkan hartanya dalam perusahaan. Sedangkan Halim (2012:58) mendefinisikan dividen sebagai suatu bentuk pembagian keuntungan atau laba kepada para pemegang saham dalam satu periode tertentu berdasarkan banyaknya saham yang dimiliki. Berdasarkan penjelasan diatas dapat disimpulkan bahwa dividen merupakan suatu pembagian laba dari suatu usaha yang diberikan kepada pemegang saham dimana laba tersebut dapat berupa dividen tunai atau dividen saham yang dapat memaksimumkan nilai perusahaan dismaping keputusan investasi dan struktur modal.

Pembagian dividen yang dilakukan perusahaan dapat diukur dengan rumus Dividend Payout Ratio (DPR), sebagai berikut:

Dividen Payout Ratio $=\frac{\text { Dividend per Share }}{\text { Earning perShare }}$

\section{Kerangka pemikiran}

Sugiyono (2019:95) menyatakan, kerangka pemikiran merupakan model konseptual tentang bagaimana teori berhubungan dengan berbagai faktor yang telah diidentifikasi sebagai masalah yang penting. Dalam penelitian ini dapat dilihat dalam gambar kerangka pemikiran sebagai berikut:

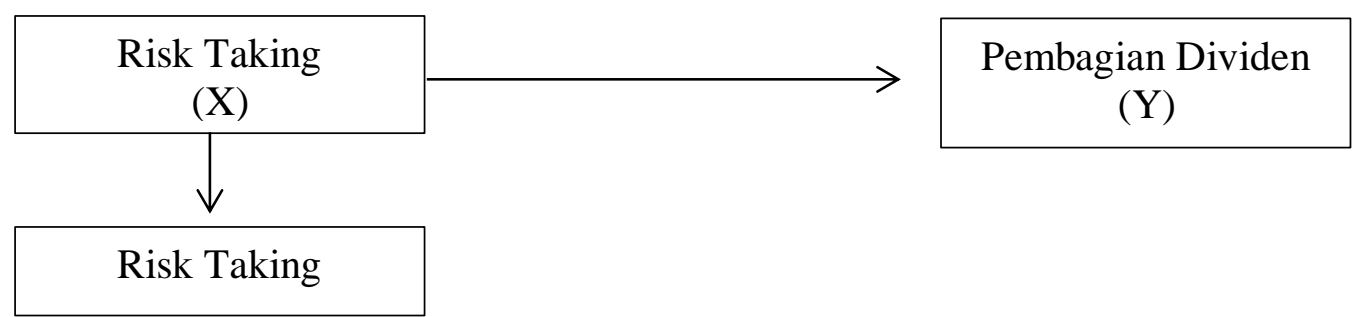

Hipotesis yang akan digunakan dalam penelitian ini berkaitan dengan ada atau tidaknya pengaruh variabel dependen terhadap variabel independen maka digunakan pengujian hipotesis nol $(\mathrm{Ho})$ dan hipotesis alternative $(\mathrm{Ha})$ yang dikembangkan sebagai berikut:

Ho : Tidak terdapat pengaruh Risk Taking terhadap pembagian Dividen

$\mathrm{Ha}$ : Terdapat pengaruh Risk Taking terhadap Pembagian Dividen

\section{METODE PENELITIAN}

Objek dan lokasi dalam penelitian ini adalah data laporan keuangan bank umum yang terdaftar di Bursa Efek Indonesia (BEI) periode 2014-2018. Metode penelitian yang digunakan adalah metode deskrptif kuantitatif, metode penelitian deskriptif kuantitatif dapat diartikan sebagai metode penelitian yang berlandasakan pada filsafat positivisme, digunakan untuk meneliti pada populasi atau sampel tertentu, pengumpulan data menggunakan instrumen penelitian, analisis data bersifat kuantitatif atau statistik, dengan tujuan untuk menguji hipotesis yang telah ditetapkan (Sugiyono, 2019:16)

Penelitian ini menggunakan dua variabel penelitian yaitu variabel independen atau variabel bebas yaitu risk-taking yang diukur dengan menggunakan z-score dan yang kedua variabel dependen atau variabel terikat yaitu pembagian dividen yang diukur dengan dividend payout ratio.

Populasi dalam penelitian ini adalah seluruh Bank Umum yang terdaftar di Bursa Efek Indonesia tahun 2014-2018 yaitu sebanyak 43 bank. Dalam penelitian ini 
sampel ditentukan dengan metode purposive sampling, metode tersebut mengambil sampel berdasarkan kriteria dan sistematika tertentu. Adapun sampel dalam penelitian ini adalah 10 Bank Umum yang terpilih sesuai kriteria.

Sumber data dalam penelitian ini adalah data sekunder, yaitu data yang diperoleh secara tidak langsung atau data yang dikumpulkan dari tangan kedua dan sumber-sumber lain yang telah tersedia sebelum penelitian ini dilakukan. Data sekunder dalam penelitian ini adalah data laporan keuangan Bank Umum yang terdaftar di Bursa Efek Indonesia pada tahun 2014-2016 yang diperoleh dari Unika Musi Charitas Palembang dan situs resmi Bursa Efek Indonesia. Metode pengambilan data dalam penelitian ini menggunakan metode dokumentasi, yaitu metode mengumpulkan data dengan jalan mencatat data penelitian yang terdapat dalam buku-buku catatan, arsip dan lain sebagainya. Metode lain yang digunakan dalam penelitian ini adalah dengan telaah pustaka, seperti memahami dan mendapatkan data melalui jurnal, buku-buku serta situs resmi yang berkaitan dengan penelitian.

Penelitian ini menggunakan pengujian statistik deskriptif dan pengujian hipotesis untuk menganalisa data, untuk menganalisis data dengan analisis regresi sederhana perhitungannya menggunakan metode satatistik yang dibantu dengan program pengolah data statistik SPSS. Sebagai syarat melakukan pengujian regresi sederhana dilakukan uji asumsi klasik untuk memastikan bahwa data penelitian memiliki sebaran data yang normal. Uji klasik dalam penelitian ini meliputi uji normalitas dan uji autokorelasi.

\section{HASIL DAN PEMBAHASAN}

Analisis deskriptif digunakan untuk memberikan gambaran atau deskripsi mengenai variabel independen yaitu Risk-taking, serta variabel dependen yaitu pembagian dividen pada Bank Umum yang terdaftar di Bursa Efek Indonesia tahun 2014-2018.

Penyajian statistik deskriptif bertujuan untuk menggambarkan karakter sampel dalam penelitian serta memberikan deskripsi variabel yang digunakan dalam penelitian. Dalam penelitian ini variabel yang digunakan adalah risk-taking dan pembagian dividen. Hasil uji statistik deskriptif disajikan pada tabel berikut ini:

Tabel Statistik Deskriptif Variabel Penelitian Descriptive Statistics

\begin{tabular}{|l|c|c|c|c|c|}
\hline & N & Min & Max & Mean & Std. Deviation \\
\hline Risk taking & 50 & -2.12 & 1.99 & .0418 & .64432 \\
Pembagian Dividen & 50 & .00 & 100.00 & 20.4636 & 22.74481 \\
Valid N (listwise) & 50 & & & & \\
\hline
\end{tabular}

Sumber: Data Diolah, 2020

\section{Uji Normalitas}

Pengujian normalitas dalam penelitian ini dilakukan dengan uji statistik yaitu uji Kolmogorov-Smirnov. Uji Kolmogorov Smirnov merupakan pengujian normalitas yang banyak dipakai, terutama setelah adanya banyak program statistik yang beredar. Kelebihan dari uji ini adalah sederhana dan tidak menimbulkan perbedaan persepsi di antara satu pengamat dengan pengamat yang lain, yang sering terjapada uji normalitas dengan menggunakan grafik. Konsep dasar dari uji normalitas Kolmogorov Smirnov adalah dengan membandingkan distribusi data (yang akan diuji normalitasnya) dengan distribusi normal baku. Jika hasil Kolmogorov-Sminrnov 
menunjukkan nilai signifikan di bawah 0,05 maka data residual tidak terdistribusi dengan normal. Sedangkan jika hasil Kolmogorov-Smirnov menunjukkan nilai signifikan di atas 0,05 maka data residual terdistribusi normal. Uji normalitas pada regresi linear tidak dilakukan per variabel, melainkan pada residual. Hasil uji normalitas dengan uji statistik 1-Sampel K-S I disajikan dalam tabel berikut ini:

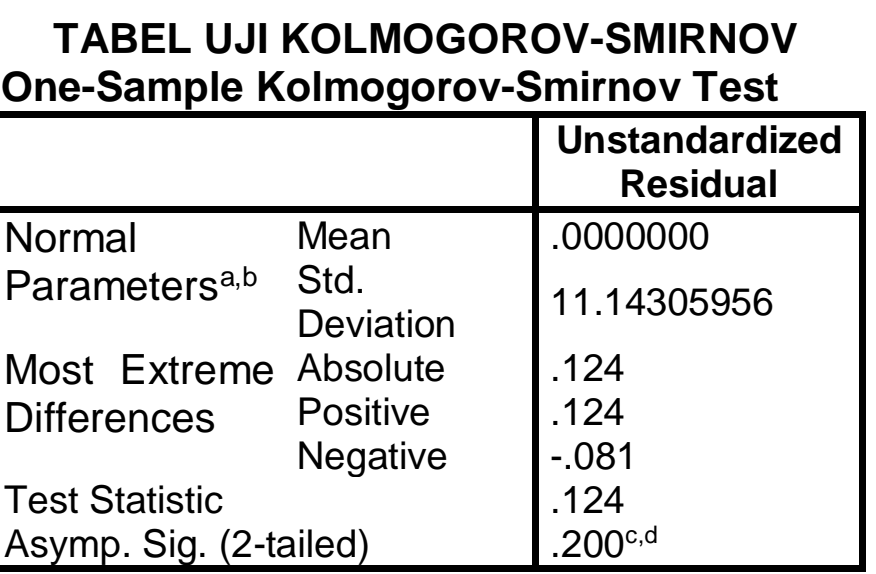

a. Test distribution is Normal.

b. Calculated from data.

c. Lilliefors Significance Correction.

d. This is a lower bound of the true significance.

Berdasarkan tabel hasil uji normalitas di atas, dapat terlihat bahwa nilai KolmogorovSmirnov persamaan regresi sebesar 0,084 signifikan di atas 0,05. Hal ini berarti bahwa model regresi memenuhi asumsi normalitas. Dari hasil uji normalitas tersebut, maka dapat disimpulkan bahwa model-model regresi dalam penelitian ini layak digunakan karena memenuhi asumsi normalitas.

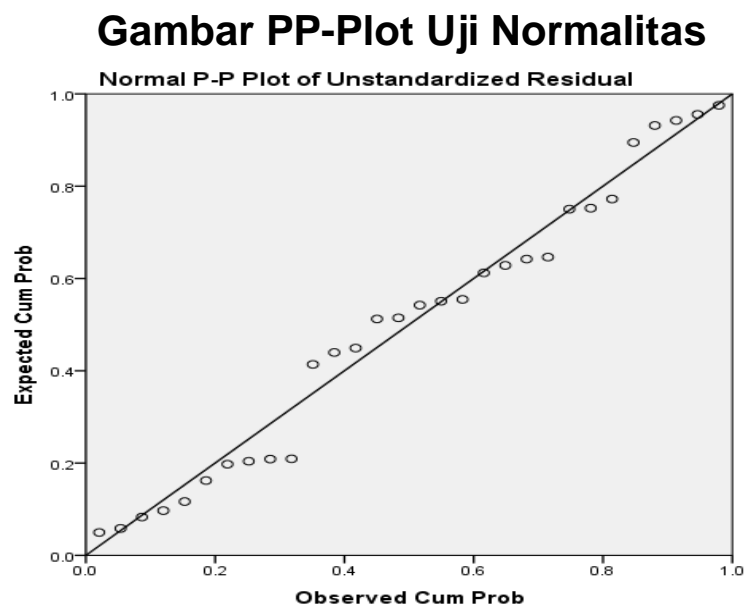

Berdasarkan gambar di atas, grafik PP-Plot yang dihasilkan mengikuti garis atas persamaan regresi. Dengan demikian, dapat disimpulkan bahwa variabel dalam penelitian ini memenuhi asumsi normalitas.

\section{Uji Autokorelasi}

Uji autokorelasi bertujuan untuk menguji apakah dalam model regresi linear ada korelasi antara kesalahan pengganggu pada periode $t$ dengan kesalahan 
pengganggu pada periode $\mathrm{t}-1$ (sebelum). Untuk hasil menguji keberadaan autokorelasi dalam penelitian ini menggunakan metode Durbin-watson dengan ketentuan sebagai berikut:

\section{TABEL HASIL PENGUJIAN AUTOKORELASI (DURBIN WARSON)} Model Summary ${ }^{\mathrm{b}}$

\begin{tabular}{|l|c|l|l|l|l|}
\hline Model & $\mathbf{R}$ & $\begin{array}{c}\mathbf{R} \\
\text { Square }\end{array}$ & $\begin{array}{c}\text { Adjusted R } \\
\text { Square }\end{array}$ & $\begin{array}{c}\text { Std. Error of } \\
\text { the Estimate }\end{array}$ & $\begin{array}{c}\text { Durbin- } \\
\text { Watson }\end{array}$ \\
\hline 1 & $.239^{\mathrm{a}}$ & .057 & .037 & 22.31497 & 1.626 \\
\hline
\end{tabular}

a. Predictors: (Constant), Risk taking

b. Dependent Variable: Pembagian Dividen

Sumber: Data Diolah, 2020

Berdasarkan output di atas, diketahui nilai DW 0,1,626. Metode pengujian yang digunakan adalah Uji Durbin-Watson (uji Dw) dengan kriteria menurut Singgih Santoso (2011:216-219) adalah sebagai berikut:

1) Jika angka D-W dibawah -2 ; kesimpulannya terjadi autokorelasi positif.

2) Jika angka D-W diantara -2 dan +2 ; maka tidak ada autokorelasi.

3) Jika angka D-W diatas +2 ; kesimpulannya terjadi autokorelasi negatif.

Berdasarkan pendapat di atas, maka nilai Durbin-Watson yang diuji sebesar 1,626 yang terletak diantara -2 dan +2 . Dengan demikian dapat disimpulkan bahwa variabel penelitian ini tidak ada autokorelasi.

\section{Pengujian Hipotesis}

Pengujian hipotesis dalam penelitian ini dilakukan untuk menghitung besarnya pengaruh dari independen terhadap variabel dependen. Pengujian hipotesis dalam penelitian ini menggunakan uji t (paried sample $t$ test) yang menunjukkan arah hubungan antara variabel dependen dengan variabel independen. Hal tersebut dapat terlihat dari hasil perhitungan regresi dipbawah ini :

Coefficients $^{\mathrm{a}}$

Tabel Hasil Perhitungan Uji t

\begin{tabular}{|c|c|c|c|c|c|c|}
\hline \multirow{2}{*}{\multicolumn{2}{|c|}{ Model }} & \multicolumn{2}{|c|}{$\begin{array}{l}\text { Unstandardized } \\
\text { Coefficients }\end{array}$} & \multirow{2}{*}{\begin{tabular}{|l}
$\begin{array}{l}\text { Standardized } \\
\text { Coefficients }\end{array}$ \\
Beta \\
\end{tabular}} & \multirow[b]{2}{*}{$t$} & \multirow[b]{2}{*}{ Sig. } \\
\hline & & B & Std. Error & & & \\
\hline 1 & $\begin{array}{l}\text { (Constant) } \\
\text { Risk taking }\end{array}$ & $\begin{array}{l}20.111 \\
8.434\end{array}$ & $\begin{array}{l}3.163 \\
4.948\end{array}$ & .239 & $\begin{array}{l}6.359 \\
1.705\end{array}$ & $\begin{array}{l}.000 \\
.095\end{array}$ \\
\hline
\end{tabular}

a. Dependent Variable: Pembagian Dividen

Sumber: Data Diolah, 2020 adalah:

Persamaan regresi antara variabel X (Risk Taking) dan Y (Pembagian Dividen)

$$
Y=20,111+8,434 X
$$

Nilai konstanta negatif $(20,111)$ dapat diartikan bahwa rata-rata kontribusi variabel lain di luar risk taking memberikan dampak positif terhadap pembagian dividen. Dari persamaan regresi tersebut menyatakan bahwa ada pengaruh positif antara variabel risk taking $(\mathrm{X})$ dan terhadap pembagian dividen $(\mathrm{Y})$. Jika risk taking meningkat maka pembagian dividen juga meningkat. Sebaliknya, jika risk taking menurun maka pembagian dividen juga menurun. 
Berdasarkan tabel di atas, didapatkan bahwa nilai t-hitung sebesar 1,705, sedangkan nilai t-tabel pada $\mathrm{dk}=\mathrm{df}=\mathrm{n}-1=50-1=49$ pada taraf $5 \%(0,05)$ sebesar 1,676551 . Selain itu, nilai signifikan untuk pengaruh risk taking terhadap pembagian dividen sebesar 0,095 > taraf signifikan 0,05 (5\%). Ini menunjukkan bahwa t-hitung = $1,705>\mathrm{t}$-tabel $=1,676551$, sehingga dapat disimpulkan bahwa risk taking berpengaruh positif dan tidak signifikan terhadap pembagian dividen pada Bank Umum yang Terdaftar di Bursa Efek Indonesia periode 2014-2018.

\section{Koefisien Determinasi}

Koefisien determinasi bertujuan untuk mengetahui seberapa besar kemampuan variabel independen menjelaskan variabel dependen. Range nilai R2 adalah 0-1, semakin mendekati 0 berarti model tidak baik atau variasi model dalam menjelaskan amat terbatas, sebaliknya semakin mendekati satu model semakin baik.

\section{Tabel Uji Koefisien Determinasi $\left(\mathbf{R}^{2}\right)$ Koefesien Determinasi Model Summary}

\begin{tabular}{|l|l|l|l|l|}
\hline Model & R & R Square & $\begin{array}{l}\text { Adjusted } \\
\text { R Square }\end{array}$ & $\begin{array}{l}\text { Std. Error of } \\
\text { the Estimate }\end{array}$ \\
\hline 1 & $.239^{\mathrm{a}}$ & .057 & .037 & 22.31497 \\
\hline
\end{tabular}

a. Predictors: (Constant), Risk taking

b. Dependent Variable: Pembagian Dividen

Berdasarkan hasil penelitian di atas, diketahui nilai $R$ sebesar 0,239 dan nilai $R^{2}$ sebesar 0,057 dengan standar error sebesar 0,037. Berdasarkan hasil pengujian koefesien determinasi di atas, maka diperoleh sebagai berikut:

$$
\begin{aligned}
& K P=r^{2} \times 100 \% \\
& K P=(0,239)^{2} \times 100 \% \\
& K P=0,057 \times 100 \% \\
& K P=5,7 \%
\end{aligned}
$$

Dengan demikian, pengaruh risk taking terhadap pembagian dividen sebesar $5,7 \%$, sedangkan sisanya sebesar $94,3 \%$ dipengaruhi oleh variabel atau faktor lain yang tidak diteliti dalam penelitian.

Berdasarkan hasil yang telah diteliti pembahasan mengenai pengaruh Risktaking terhadap pembagian dividen pada bank umum didapatkan dengan metode statistik deskriptif , uji asumsi klasik meliputi uji normalitas, uji autokorelasi, koefisien determinasi, dan model uji t. Dari hasil persamaan regresi antara variabel $X$ dan $Y$ regresi tersebut menyatakan bahwa ada pengaruh positif antara variabel risk-taking (X) dan terhadap pembagian dividen (Y). Jika risk-taking meningkat maka pembagian dividen juga meningkat. Sebaliknya, jika risk-taking menurun maka pembagian dividen juga menurun.

Berdasarkan tabel diatas didapatkan bahwa nilai t-hitung sebesar 1,705, sedangkan nilai t-tabel pada $\mathrm{dk}=\mathrm{df}=\mathrm{n}-1=50-1=49$ pada taraf $5 \%(0,05)$ sebesar 1,676551 . Selain itu, nilai signifikan untuk pengaruh risk taking terhadap pembagian dividen sebesar 0,095 > taraf signifikan 0,05 (5\%). Ini menunjukkan bahwa t-hitung = $1,705>\mathrm{t}$-tabel $=1,676551$, sehingga dapat disimpulkan bahwa risk taking berpengaruh positif dan tidak signifikan terhadap pembagian dividen pada Bank Umum yang Terdaftar di Bursa Efek Indonesia periode 2014-2018. 
Berdasarkan hasil penelitian, diketahui nilai $R$ sebesar 0,239 dan nilai $R 2$ sebesar 0,057 dengan standar error sebesar 0,037. Dengan demikian, pengaruh risk-taking terhadap pembagian dividen sebesar 5,7\%, sedangkan sisanya sebesar $94,3 \%$ dipengaruhi oleh variabel atau faktor lain yang tidak diteliti dalam penelitian ini.

Hasil penelitian ini membuktikan bahwa ada pengaruh risk taking terhadap pembagian dividen pada Bank Umum yang Terdaftar di Bursa Efek Indonesia periode 2014-2018. Tetapi, pengaruh yang dihasilkan tidak signifikan. Risk-taking bukan merupakan satu-satunya faktor yang mempengaruhi kebijakan dividen suatu bank. Terdapat beberapa faktor yang dapat menjelaskan mengapa argumen dalam hipotesis tidak diterima. Faktor yang pertama adalah ketaatan bank pada undangundang (peraturan). Bank memilih untuk taat dari pada memanfaatkan celah undangundang (peraturan) yang berlaku untuk mengambil keuntungan privat. Dalam risktaking yang tinggi, bank lebih memilih menahan labanya dan tidak membagikan dividen. Kemungkinan yang terjadi yaitu bank memanfaatkan laba tersebut untuk menjaga kecukupan modal (capital adequacy) sesuai dengan ketentuan Bank Indonesia. Argumen ini mengacu kepada Peraturan Bank Indonesia Nomor:10/15/PBI/2008 Tentang Kewajiban Penyediaan Modal Minimum Bank Umum.

\section{E. KESIMPULAN DAN SARAN}

1) Kesimpulan

Berdasarkan hasil penelitian yang telah dilakukan maka dapat disimpulkan sebagai berikut:

a. Nilai t-hitung sebesar 1,705 > nilai t-tabel sebesar 1,676551, sehingga dapat disimpulkan bahwa risk taking berpengaruh positif dan tidak signifikan terhadap pembagian dividen pada Bank Umum yang Terdaftar di Bursa Efek Indonesia periode 2014-2018.

b. Pengaruh risk taking terhadap pembagian dividen sebesar 5,7\%, sedangkan sisanya sebesar $94,3 \%$ dipengaruhi oleh variabel atau faktor lain yang tidak diteliti dalam penelitian.

2) Saran

Beberapa saran yang dapat diberikan penulis berkaitan dengan hasil penelitian ini adalah sebagai berikut:

a. Bagi pihak perbankan diharapkan dengan adanya penelitian ini dapat dijadikan pengetahuan dan informasi mengenai risk-taking dan pembagian dividen, sehingga dapat memperhatikan risk-taking dan pembagian dividen tersebut agar mendapatkan ekuitas yang lebihb baik.

b. Untuk peneliti selanjutnya lebih disarankan untuk menambah jumlah variabel. Pengembangan variabel perlu dilakukan mengingat banyak variabel lain yang berperan dalam pembagian dividen seperti, Retrun on Asset, Cash Flow, Cash Ratio, Asset Growth, yang dapat dipertimbangkan untuk penelitian selanjutnya dan diharapakan peneliti selanjutnya dapat menambah jumlah tahun penelitian, agar penelitian selanjutnya lebih sempurna dan lebih baik. 


\section{DAFTAR PUSTAKA}

Bank Indonesia (2003). Peraturan Bank Indonesia Nomor: 5/8/PBI/2003 Tentang Penerapan Manajemen Risiko Bagi Bank Umum. Jakarta

Halim, Abdul. (2012). Akuntansi Sektor Publik Akuntansi Keuangan Daerah, Edisi Revisi, Jakarta: Salemba Empat

Indrayani, dan Aprina.(2017). Pengaruh Risk Taking dan Free cash Flow Terhadap Pembagian Dividen (Studi Empiris Pada Bank Umum Yang Terdaftar di Bursa Efek Indonesia). Jurnal Akuntansi Dan Keuangan: Volume 5, Nomor 1, Februari 2017 ISSN: 2301-4717.

Kinanti, Regina Galuh dan I Putu Sugiartha Sanjaya (2015).Pengaruh Risk Taking Terhadap Pembagaian Dividen(Studi Empiris Pada Bank Umum Yang Terdaftar Di BEI Tahun 2004-2013). Universitas Atma Jaya Yogyakarta, Jalan Babarsari 43-44, Yogyakarta.

Rudianto.(2012). Pengantar Akuntansi Konsep dan Tehnik Penyusunan Laporan keuangan. Jakarta: Erlangga

Sugiyono. (2019). Metode Penelitian Kuantitatif Kualitatf dan R\&D. Bandung: Alfabeta.

Undang-Undang Republik Indonesia.(2009). Undang-Undang Republik Indonesia Nomor 6 Tahun 2009 Tentang Penetapan Peraturan Pemerintah Penganti Undang-Undang Nomor 2 Tahun 2008 Tentang Bank Indonesia. Jakarta.

Supardi. (2016). Aplikasi Statistika dalam Penelitian Konsep Statistika yang Lebih Komprehensif. Jakarta : Prima Ufuk 